\author{
DEPARTMENT OF THE INTERIOR \\ UNITED STATES GEOLOGICAL SURVEY
}

\title{
AEROMAGNETIC MAP OF THE THOMPSON LAKES QUADRANGLE LINCOLN, SANDERS, AND FLATHEAD COUNTIES, MONTANA
}

\author{
GEOPHYSICAL INVESTIGATIONS \\ MAP GP-683
}

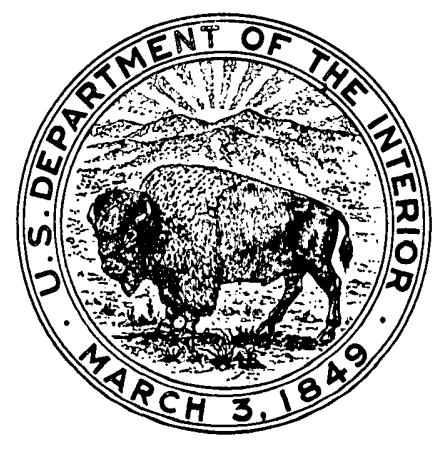

PUBLISHED BY THE U. S. GEOLOGICAL SURVEY 